\title{
Adjuvant chemotherapy in advanced nasopharyngeal carcinoma based on plasma EBV load
}

\author{
Jin-Ching Lin
}

Received: 25 April 2012 /Accepted: 26 April 2012 / Published online: 12 May 2012

(C) Springer-Verlag 2012

\begin{abstract}
Nasopharyngeal carcinoma (NPC) has been shown to be a radio- and chemosensitive tumor and combined chemoradiotherapy is the standard of care for advanced-stage patients. Different chemotherapy strategies (neoadjuvant, concurrent, adjuvant) are incorporated with radiotherapy to enhance treatment outcome and each mode of combined therapy has advantages and disadvantages. There are many randomized clinical trials investigating the role of adding chemotherapy in NPC management. So far, concurrent and neoadjuvant chemotherapy are more frequently used for locoregionally advanced tumors. However, the current reality is that (1) distant failure is the most frequent site of relapse reported in all studies, (2) patients have already received neoadjuvant and/or concurrent chemotherapy, and (3) only some tumors recur after previous neoadjuvant/concurrent chemotherapy with radiotherapy. So, adjuvant chemotherapy is a reasonable timing to consolidate the treatment outcome for selected patients. Recently, several tumor markers can predict tumors with high probability of recurrence. Among these markers, plasma EBV DNA assay is a simple and reliable one in predicting prognosis. In this mini-review, I will focus on the role of adjuvant chemotherapy based on plasma EBV DNA load.
\end{abstract}

\footnotetext{
J.-C. Lin

Institute of Clinical Medicine, School of Medicine,

National Yang-Ming University,

Taipei, Taiwan

J.-C. Lin $(\square)$

Department of Radiation Oncology,

Taichung Veterans General Hospital,

No. 160, Sec. 3, Taichung-Kang Rd.,

Taichung City 407, Taiwan

e-mail: jclin@vghtc.gov.tw
}

Keywords Nasopharyngeal carcinoma · Radiotherapy · Adjuvant chemotherapy $\cdot$ Epstein-Barr virus

\section{Introduction}

Nasopharyngeal carcinoma (NPC) is a geographically endemic, Epstein-Barr virus (EBV)-associated carcinoma of epidermoid origin. Because of the inherent anatomic constraints and a high degree of radiosensitivity, radiotherapy (RT) has been the primary treatment for NPC patients. NPC is also a chemosensitive tumor. Various modes of combined chemoradiotherapy have been used to treat NPC patients with advanced-stage diseases during recent 20 years. However, treatment outcome for locoregionally advanced NPC is still unsatisfactory. Table 1 lists survival outcome from some larger series with adequate follow-up [1-7]. The 5 -year relapse/progression-free survival rates for patients with stage III and IV disease were $47-62 \%$ and $30-44 \%$, respectively. The overall survival rates at 5 years were 55 $80 \%$ and $28-61 \%$ in stage III and IV, respectively. These data indicate that there is much room for improvement.

Recent advances in cancer biology have developed many clinically useful biomarkers that can aid in risk grouping of patients with similar stage and guidance of optimal treatment for each patient, such as epidermal growth factor receptor mutations in non-small cell lung cancer, KRAS mutation in colorectal cancer, methylation status of the $M G M T$ promoter in glioblastoma, etc. It is difficult to get adequate tumor specimens for biomarkers research in NPC because it is basically treated without surgery. Recently, cell-free circulating EBV DNA can be detected in plasma and serum of NPC patients and has been shown to hold promise as a reliable biomarker in the detection, monitoring, and prediction of outcome for NPC [8-18]. This mini- 
Table 1 Survival data for stage III-IV nasopharyngeal carcinoma
AJCC American Joint Committee on Cancer, $O S$ overall survival, $P F S$ progression-free survival, $D F S$ disease-free survival, $F F R$ failure-free survival, $R T$ radiotherapy, $C h$ chemotherapy, $N A$ not available

\begin{tabular}{|c|c|c|c|c|c|c|c|}
\hline \multirow[t]{2}{*}{ Series } & \multirow[t]{2}{*}{ No. of cases } & \multirow[t]{2}{*}{ Staging system } & \multirow[t]{2}{*}{ Treatment } & \multicolumn{2}{|l|}{$5-y$ OS } & \multicolumn{2}{|c|}{ 5-y PFS/DFS/FFS } \\
\hline & & & & Stage III & Stage IV & Stage III & Stage IV \\
\hline Heng et al. [1] & 677 & 1997 AJCC & RT & $60 \%$ & $35-28 \%$ & NA & NA \\
\hline Ma et al. [2] & 621 & 1997 AJCC & RT & $53 \%$ & $37 \%$ & $51 \%$ & $36 \%$ \\
\hline Yeh et al. [3] & 849 & 1997 AJCC & RT & $55 \%$ & $42-39 \%$ & $47 \%$ & $31-30 \%$ \\
\hline Au et al. [4] & 1294 & 1997 AJCC & RT & $\square$ & $\square$ & $69 \%$ & $39 \%$ \\
\hline Chua et al. [5] & 324 & 1997 AJCC & $\mathrm{RT} \pm \mathrm{Ch}$ & $80 \%$ & $61 \%$ & $55 \%$ & $41 \%$ \\
\hline Leung et al. [6] & 1070 & 1997 AJCC & $\mathrm{RT} \pm \mathrm{Ch}$ & $62 \%$ & $44-43 \% *$ & $57 \%$ & $42-43 \%$ \\
\hline Lee et al. [7] & 2687 & 1997 AJCC & $\mathrm{RT} \pm \mathrm{Ch}$ & $75 \%$ & $58 \%$ & $62 \%$ & $44 \%$ \\
\hline Lai et al. [31] & 764 & 2002 AJCC & $\mathrm{RT} \pm \mathrm{Ch}$ & NA & NA & $75.6 \%$ & $53.1 \%$ \\
\hline Lai et al. [31] & 512 & 2002 AJCC & $\mathrm{RT} \pm \mathrm{Ch}$ & NA & NA & $76.5 \%$ & $54.9 \%$ \\
\hline
\end{tabular}

review will focus on the role of adjuvant chemotherapy based on plasma EBV DNA load.

\section{Patterns of failure}

Information detailing treatment-failure patterns is important in designing new treatment protocols. Before 1990, larger series from endemic areas [18-24] and nonendemic regions [25-30] reported that treatment failure was due to both a high rate of local recurrence (ranging from $10.2 \%$ to $31.0 \%$ in endemic areas and $26.0 \%$ to $63.3 \%$ in non-endemic regions) and distant metastasis (ranging from $24.0 \%$ to $43.5 \%$ in endemic areas and $12.7 \%$ to $36.3 \%$ in non-endemic regions). Since the transition from two-dimensional RT to 3D/IMRT-based $\mathrm{RT}$, the failure of treatment for NPC predominantly has been due to distant metastasis. Table 2 summarizes the patterns of failure from several larger series for NPC patients treated with non-IMRT techniques $[2,3,6,7$, 31-36]. A total of 7,319 patients were collected from 8 reports; there were $1,100(15.0 \%)$ local recurrences, $403(5.5 \%)$ regional recurrences, and 1,666 (22.8\%) distant failures. In contrast, in the latest reports [31, 37-47] the observed relapse rates in local, regional, and distant sites are substantially better, most likely due to improvements in RT and to greater use of combined chemotherapy. Table 3 presents data from 1826 patients in 12 studies and shows local, regional, and distant failures in $112(6.1 \%), 59(3.4 \%)$, and $218(12.4 \%)$ patients, respectively. Although the follow-up periods of these studies are too short to permit a definite conclusion, I believe that the higher locoregional control rate is achievable using modern radiation techniques alone for early-stage tumors and combined chemoradiotherapy for advanced-stage tumors.

Table 2 Patterns of failure for nasopharyngeal carcinoma treated with non-IMRT technique

\begin{tabular}{|c|c|c|c|c|c|c|c|}
\hline \multirow[t]{2}{*}{ Series } & \multirow[t]{2}{*}{ Cases } & \multirow[t]{2}{*}{ Treatment } & \multirow[t]{2}{*}{ Follow-up (median) } & \multicolumn{4}{|l|}{ Failure site(s) } \\
\hline & & & & Local & Regional & Distant & Locoregional \\
\hline Hong et al. [32]; SYSU, China & 411 & RT & NA & $76(18.5 \%)$ & $20(4.9 \%)$ & $82(20.0 \%)$ & \\
\hline Ma et al. [2]; SYSU, China & 621 & RT & $60 \mathrm{~m}$ & $109(17.6 \%)$ & $44(7.1 \%)$ & $136(21.9 \%)$ & \\
\hline Yeh et al. [3]; KSCGMH, Taiwan & 849 & RT & $112 \mathrm{~m}$ & $188(22.1 \%)$ & $55(6.5 \%)$ & $227(26.7 \%)$ & \\
\hline Lee et al. [7]; HK & 2,687 & $\mathrm{RT} \pm \mathrm{Ch}$ & $40.8 \mathrm{~m}$ & $12 \%$ & $5 \%$ & $16 \%$ & \\
\hline Leung et al. [6]; TMH, HK & 1,070 & $\mathrm{RT} \pm \mathrm{Ch}$ & $56 \mathrm{~m}$ & $190(17.8 \%)$ & $72(6.7 \%)$ & $245(22.9 \%)$ & \\
\hline Lu et al. [33]; JSCH, China & 159 & RT & $61 \mathrm{~m}$ & $18(11.3 \%)$ & $12(7.5 \%)$ & $33(20.8 \%)$ & \\
\hline Liu et al. [34]; SYSU, China & 749 & $\mathrm{RT} \pm \mathrm{Ch}$ & $62 \mathrm{~m}$ & $110(14.7 \%)$ & $32(4.3 \%)$ & $133(17.8 \%)$ & \\
\hline Lai et al. [31]; SYSU, China & 764 & $\mathrm{RT} \pm \mathrm{Ch}$ & $52.8 \mathrm{~m}$ & $87(11.4 \%)$ & $34(4.5 \%)$ & $134(17.5 \%)$ & \\
\hline Sum of above & 7,319 & & & $1100(15.0 \%)$ & $403(5.5 \%)$ & $1666(22.8 \%)$ & \\
\hline Cheng et al. [35]; KFSYSCC, Taiwan & 630 & $\mathrm{RT} \pm \mathrm{Ch}$ & $58 \mathrm{~m}$ & NA & NA & $96(15.2 \%)$ & $60(9.5 \%)$ \\
\hline Yi et al. [36]; CHCAMS, China & 905 & RT & $105 \mathrm{~m}$ & NA & NA & $150(16.6 \%)$ & $130(14.4 \%)$ \\
\hline
\end{tabular}

$I M R T$ intensity-modulated radiotherapy, $R T$ radiotherapy, $N A$ not available, $C h$ chemotherapy, $m$ month, SYSU Sun Yat-sen University, KSCGMH Kaohsiung Chang Gung Memorial Hospital, HK Hong Kong, TMH Tuen Mun Hospital, JSCH Jiangsu Cancer Hospital, KFSYSCC Koo Foundation Sun Yat-Sen Cancer Center, CHCAMS Cancer Hospital of Chinese Academy of Medical Sciences 
Table 3 Patterns of failure for nasopharyngeal carcinoma treated with IMRT technique

\begin{tabular}{|c|c|c|c|c|c|c|c|}
\hline \multirow[t]{2}{*}{ Series } & \multirow[t]{2}{*}{ Cases } & \multirow[t]{2}{*}{ Stage } & \multirow[t]{2}{*}{ Treatment } & \multirow[t]{2}{*}{ Follow-up (median) } & \multicolumn{3}{|l|}{ Failure site(s) } \\
\hline & & & & & Local & Regional & Distant \\
\hline Kwong et al. [37]; QMH, HK & 50 & III-IVB & $\mathrm{RT} \pm \mathrm{Ch}$ & $25 \mathrm{~m}$ & $4(8.0 \%)$ & $2(4.0 \%)$ & $2(4.0 \%)$ \\
\hline Wolden et al. [38]; MSKCC, US & 74 & I-IVB & $\mathrm{RT} \pm \mathrm{Ch}$ & $35 \mathrm{~m}$ & $6(22.1 \%)$ & NA & NA \\
\hline Kam et al. [39]; PWH, HK & 63 & I-IVB & $\mathrm{RT} \pm \mathrm{Ch}$ & $29 \mathrm{~m}$ & $4(6.3 \%)$ & $1(1.6 \%)$ & $13(20.6 \%)$ \\
\hline Lee et al. [40]; UCSF, US & 67 & I-IVB & $\mathrm{RT} \pm \mathrm{Ch}$ & $31 \mathrm{~m}$ & $1(1.5 \%)$ & $1(1.5 \%)$ & $17(25.4 \%)$ \\
\hline Xiao et al. [41]; SYSU, China & 81 & III-IVA & $\mathrm{RT}+\mathrm{Ch}$ & $54 \mathrm{~m}$ & $4(4.9 \%)$ & $2(2.5 \%)$ & $14(17.3 \%)$ \\
\hline Lee et al. [42]; RTOG0225 & 68 & I-IVB & $\mathrm{RT} \pm \mathrm{Ch}$ & $31.2 \mathrm{~m}$ & $5(7.4 \%)$ & $6(8.8 \%)$ & $10(14.7 \%)$ \\
\hline Lin et al. [43]; CHFJMU, China & 323 & II-IVB & $\mathrm{RT} \pm \mathrm{Ch}$ & $30 \mathrm{~m}$ & $12(3.7 \%)$ & $6(1.9 \%)$ & $26(8.0 \%)$ \\
\hline Tham et al. [44]; Singapore & 195 & I-IVB & $\mathrm{RT} \pm \mathrm{Ch}$ & $36.5 \mathrm{~m}$ & $19(9.7 \%)$ & $5(2.6 \%)$ & $19(9.7 \%)$ \\
\hline Wong et al. [45]; TMH and QMH, HK & 175 & I-IVB & $\mathrm{RT} \pm \mathrm{Ch}$ & $34 \mathrm{~m}$ & $10(5.7 \%)$ & $11(6.3 \%)$ & $20(11.4 \%)$ \\
\hline Ng et al. [46]; PYNEH HK & 193 & $\mathrm{I}-\mathrm{IVB}$ & $\mathrm{RT} \pm \mathrm{Ch}$ & $30 \mathrm{~m}$ & $16(8.3 \%)$ & $9(4.7 \%)$ & $23(11.9 \%)$ \\
\hline Lai et al. [31]; SYSU, China & 512 & I-IVB & $\mathrm{RT} \pm \mathrm{Ch}$ & $52.8 \mathrm{~m}$ & $29(5.7 \%)$ & $14(2.7 \%)$ & $72(14.1 \%)$ \\
\hline Bakst et al. [47]; MSKCC, US & 25 & II-IVB & $\mathrm{RT}+\mathrm{Ch}$ & $33 \mathrm{~m}$ & $2(8 \%)$ & $2(8 \%)$ & $2(8 \%)$ \\
\hline Sum of above & 1,826 & & & & $112(6.1 \%)$ & $59(3.4 \%)$ & $218(12.4 \%)$ \\
\hline
\end{tabular}

$I M R T$ intensity-modulated radiotherapy, $R T$ radiotherapy, $C h$ chemotherapy, $N A$ not available, $m$ month, $Q M H$ Queen Mary Hospital, $H K$ Hong Kong, MSKCC Memorial Sloan-Kettering Cancer Center, US United State, PWH Prince of Wales Hospital, UCSF University of California-San Francisco, SYSU Sun Yat-sen University, RTOG Radiation Therapy Oncology Group, CHFJMU Cancer Hospital of Fujian Medical University, TMH Tuen Mun Hospital, PYNEH Pamela Youde Nethersole Eastern Hospital

\section{Approaches that reduce distant failures}

Search for useful markers in predicting distant failure

There is no debate that systemic failures need systemic treatment and the identification of high-risk patients who have a higher probability of subsequent distant failures is the first step for success. Many prognostic markers, including disease-, host-, and treatment-related parameters, have been reported in NPC. Among these, N-classification, overall stage, and plasma EBV DNA (pEBV DNA) load currently are the most useful. N-classification plays a critical role in predicting distant failure. The reported 5-year metastasisfree survival rates for patients with $\mathrm{N} 0, \mathrm{~N} 1, \mathrm{~N} 2$, and $\mathrm{N} 3$ were $87-93 \%, 76-84 \%, 62-81 \%$, and 51-73\%, respectively [2, 4, 36]. Metastasis-free survival rates were also affected by the overall stage and showed a gradual decrease from $93 \%$ to $98 \%$ (stage I), 77-95\% (stage II), 76-80\% (stage III), to 56-71\% (stage IV), respectively [5-7]. The disease-free or progression-free survival rates at 5 years for patients with stage I, II, III, and IV were 76-95 \%, 65-88 \%, $47-77 \%$, and $30-55 \%$, respectively [2, 3, 5-7, 36]. Thus, patients with $\mathrm{N} 3$ or overall stage IV disease clearly are at greatest risk.

NPC has been proven as an EBV-associated cancer for a long time. Evidences of (1) the presence of DNA, RNA, and proteins of EBV in almost all cancer cells of almost all tissue samples (primary and various metastatic sites) obtained from patients with NPC [48-50], (2) tumor cells proved to be derived from a single EBV-infected cell [51], and (3) high levels of EBV protein antibodies in newly found NPC patients [52-54] and in healthy individuals in whom NPC later developed $[55,56]$ suggested that EBV may serve as a marker for NPC. Recent development of the real-time quantitative polymerase chain reaction assay allows us to detect circulating EBV DNA fragments in most newly diagnosed NPCs [8-17]. In addition, pEBV DNA is rarely detected in healthy people and long-term survivors of NPC without relapse [8, 14]. Lin et al. found a concordant decrease pattern of EBV DNA level in both primary tumor cells and plasma samples after neoadjuvant chemotherapy (NeoCT) along with consistent genotyping of EBV DNA between paired samples of plasma and primary tumor strongly suggesting that the circulating cell-free EBV DNA originates from the primary tumor [14]. The pretreatment $\mathrm{pEBV}$ DNA concentrations have been shown to correlate with the clinical stages of NPC [8, 14-16]. Ma et al. further analyzed the relationship between the $\mathrm{pEBV}$ DNA level with MRI-delineated tumor volume and with tumor metabolic activity by PET/CT scan and showed that circulating EBV DNA level reflects overall tumor load [57]. Furthermore, studies from endemic area [8-16] observed that (1) the pEBV DNA decreases to normal after treatment in patients with complete remission but remains elevated in patients with residual disease, (2) the pEBV DNA increases simultaneously or in advance of clinical tumor relapse, and (3) the level of the pEBV DNA can predict an individual patient's survival and prognosis. All data from high- 
incidence areas consistently illustrate that quantification of pEBV DNA is an ideal tumor marker for NPC. Recent studies from low-incidence countries also showed similar results [17, 58-60]. More importantly, pEBV DNA assay is a simple and hospital-based laboratory test with quantitative information.

Although the pre-treatment pEBV DNA load can detect high-risk tumors $[8,10-16]$, post-treatment $p E B V$ DNA levels also have prognostic importance and the post-treatment viral load dominates the effect of the pre-treatment load [11, 14-17]. Chan et al. recruited 170 NPC patients who received a uniform RT protocol with/without chemotherapy. After a short follow-up (median 116 weeks), they observed that the 1 -year progression-free survival rates for patients who had post-treatment viral load of less than 500 copies $/ \mathrm{mL}$ versus more than 500 copies $/ \mathrm{mL}$ were $93 \%$ and $48 \%$, respectively [11]. Using a cutoff $=4,000$ copies $/ \mathrm{mL}$ for pre-treatment pEBV DNA and a cutoff of 500 copies $/ \mathrm{mL}$ for posttreatment $\mathrm{pEBV}$ DNA, they divided patients into four subgroups with 1-year survival rates of $32 \%$ (high post and high pre), $50 \%$ (high post and low pre), $84 \%$ (low post and high pre), and $97 \%$ (low post and low pre). By retrospective measurement of plasma samples from 152 NPC patients who received a uniform protocol of concurrent chemoradiotherapy (CCRT) and a median follow-up of 78 months, Lin et al. could stratify patients into 3 different groups with 5 -year overall survival and relapse-free survival rates of $87.2 \%$, $71.0 \%, 38.7 \%(P<0.0001)$, and $85.6 \%, 75.9 \%$, and $26.9 \%(P<0.0001)$, respectively, by combined pretreatment and post-treatment pEBV DNA levels [15]. In another group of 210 NPC patients prospectively treated by $\mathrm{NeoCT}+\mathrm{RT}$ with a minimum follow-up of 6 years, Lin et al. observed similar results (unpublished data). The 5-year overall survival (59.2 \% vs. $86.0 \%, P=0.0003)$ and relapse-free survival (56.5\% vs. $79.3 \%, P<0.0001)$ were significantly lower in patients with pretreatment $\mathrm{pEBV}$ DNA $\geq 1,500$ copies $/ \mathrm{mL}$ than in those with pEBV DNA $<1,500$ copies $/ \mathrm{mL}$. Patients with persistently detectable pEBV DNA 1 week after NeoCTRT had significant worse overall $(33.3 \%$ vs. $79.4 \%, P<$ $0.0001)$ and relapse-free survivals $(23.3 \%$ vs. $75.6 \%, P<$ $0.0001)$ than those with undetectable pEBV DNA. Le et al. from the Stanford University reported a significant correlation between post-treatment pEBV DNA levels and freedomfrom-relapse or overall survival in 58 newly diagnosed NPC patients [17]. The 2-year freedom-from-relapse and overall survival rates were $92 \%$ and $94 \%$ for patients with undetectable and $37 \%$ and $55 \%$ for those with persistently detectable post-treatment pEBV DNA levels $(P<0.0001$ and $P<0.002)$. Hou et al. collected 69 NPC patients and observed that patients with post-treatment detectable $\mathrm{pEBV}$ DNA had worse 5 -year metastasis-free survival ( $50.0 \%$ vs. $91.2 \%, P<0.001)$ and overall survival $(50.0 \%$ vs. $91.2 \%, P<0.001)$ than those with undetectable pEBV DNA [16]. In summary, patients with persistently detectable post-treatment pEBV DNA or high pre-treatment $p E B V$ DNA load represent the subgroup having the highest risk.

Search for a more effective treatment protocol

Combined chemoradiotherapy has been accepted by most oncologists as the standard treatment of advanced NPC. There is still great controversy, however, regarding the optimal drugs, timing, dosage, and duration of chemotherapy. In general, there are three different ways to incorporate chemotherapy into a curative course of RT: NeoCT, concurrent chemotherapy, and adjuvant chemotherapy (AdjCT) that are delivered before, during, and after RT. Each mode of combined therapy has advantages and disadvantages and has been extensively investigated during past years. In brief speaking, the major flaws of NeoCT are triggering of accelerated repopulation and cross-resistance during subsequent RT. The dose intensity of concurrent chemotherapy that can be delivered safely during 7-8 weeks RT is usually lower than in NeoCT or AdjCT setting. This may compromise its efficacy in eradication of micrometastasis. Poor compliance and compromised blood supply are the two major problems of AdjCT.

To the best of my knowledge, there are 21 randomized clinical trials investigating the role of adding chemotherapy in NPC treatment [61-89]. Unfortunately, the results are somewhat confusing at first glance. The most important trial is the Intergroup study 0099 published in 1998 [64]. Using concurrent cisplatin (P) $100 \mathrm{mg} / \mathrm{m}^{2}$ every 3 weeks during RT followed by 3 cycles post-radiation AdjCT of cisplatin $80 \mathrm{mg} / \mathrm{m}^{2}$ day 1+5-fluorouracil (F) $1,000 \mathrm{mg} / \mathrm{m}^{2}$ days $1-4$, Al-Sarraf et al. reported that CCRT+AdjCT is superior to RT alone. Of 193 patients with 1987 AJCC/UICC stage III-IV (re-staged to II-IVB by 1997 AJCC staging system) registered, 147 were eligible for analysis. The 3-year progression-free survival (69 \% vs. $24 \%, P<0.001)$ and overall survival (78 \% vs. $47 \%, P=0.005$ ) favored for the combined chemoradiotherapy group. Since then, this regimen has become the standard of care for advanced NPC patients. Using the same design (CCRT+AdjCT vs. RT alone), same chemotherapeutic agents and same/similar chemotherapy dose intensity, four subsequent trials [72, 73, 75, 76] from endemic areas (one from Singapore, two from Hong Kong, one from China) generally have supported the results of the Intergroup study. Table 4 shows some pertinent parameters and outcome of these trials with updated data [81-85]. The overall survival and progression-free/disease-free/failure-free survival rates are significant higher in the CCRT + AdjCT arm (all $P<0.05$ ). In my view, the major treatment is RT and both concurrent and adjuvant chemotherapy are integral parts of the protocol. It is difficulty and unnecessary to differentiate which parts of chemotherapy contribute more to the outcome. There were 
Table 4 Randomized trials of CCRT+AdjCT vs RT alone

\begin{tabular}{|c|c|c|c|c|c|c|}
\hline Series & Stage & Cases & ${ }^{\mathrm{a}}$ Concurrent CT; AdjCT & $\begin{array}{l}\text { Follow-up } \\
\text { (median) }\end{array}$ & $\begin{array}{l}\text { 5-y OS } \\
\text { CCRT+AdjCT vs RT }\end{array}$ & $\begin{array}{l}\text { 5-y PFS/DFS/FFS } \\
\text { CCRT+AdjCT vs RT }\end{array}$ \\
\hline $\begin{array}{l}\text { Al-Sarraf et al. [64, 81]; } \\
\text { Intergroup } 0099\end{array}$ & II-IV & 147 & $\begin{array}{l}\mathrm{P} 100 \mathrm{q} 3 \mathrm{w} \times 3 ; \mathrm{P} 80 \mathrm{~F} 1000 \mathrm{~d} 1-4 \\
\mathrm{q} 4 \mathrm{w} \times 3\end{array}$ & $>5 \mathrm{y}$ & $67 \%$ vs $37 \%(P=0.001)$ & $58 \%$ vs $29 \%(P<0.001)$ \\
\hline $\begin{array}{l}\text { Wee et al. }[73,82] \\
\text { Singapore }\end{array}$ & II-IV & 221 & $\begin{array}{l}\mathrm{P} 25 \mathrm{~d} 1-4 \mathrm{q} 3 \mathrm{w} \times 3 ;(\mathrm{P} 20 \mathrm{~F} 1000) \\
\mathrm{d} 1-4 \mathrm{q} 4 \mathrm{w} \times 3\end{array}$ & $4.9 \mathrm{y}$ & $65 \%$ vs $46 \%(P=0.0106)$ & $55 \%$ vs $45 \%(P=0.0393)$ \\
\hline $\begin{array}{l}\text { Chen et al. [76]; } \\
\text { SYSU, China }\end{array}$ & III-IV & 316 & $\begin{array}{l}\mathrm{P} 40 \mathrm{qw} \times 7 ; \mathrm{P} 80 \mathrm{~F} 800 \mathrm{~d} 1-5 \\
\mathrm{q} 4 \mathrm{w} \times 3\end{array}$ & $29 \mathrm{~m}$ & $89.8 \%$ vs $79.7 \%(P=0.003)$ & $84.6 \%$ vs $72.5 \%(P=0.001)$ \\
\hline $\begin{array}{l}\text { Lee et al. }[72,83] \\
\text { NPC 9901, HK }\end{array}$ & III-IV & 348 & $\begin{array}{l}\text { P100 q3w } \times 3 ; \text { P } 80 F 1000 d 1-4 \\
q 4 w \times 3\end{array}$ & $2.3 \mathrm{y}$ & & \\
\hline $\begin{array}{l}\text { Lee et al. }[75,84] \\
\text { NPC } 9902, \mathrm{HK}\end{array}$ & III-IV & 189 & $\begin{array}{l}\text { P100 q3w } \times 3 ; \text { P80F1000d1-4 } \\
q 4 w \times 3\end{array}$ & $2.9 \mathrm{y}$ & & \\
\hline $\begin{array}{l}\text { Lee et al. [85]; } \\
\text { NPC } 9901+\text { NPC } 9902\end{array}$ & III-IV & 441 & $\begin{array}{l}\mathrm{P} 100 \mathrm{q} 3 \mathrm{w} \times 3 ; \mathrm{P} 80 \mathrm{~F} 1000 \mathrm{~d} 1-4 \\
\mathrm{q} 4 \mathrm{w} \times 3\end{array}$ & $6.1 \mathrm{y}$ & $72 \%$ vs $63 \%(P=0.037)$ & $68 \%$ vs $55 \%(P=0.002)$ \\
\hline
\end{tabular}

CCRT concurrent chemoradiotherapy, AdjCT adjuvant chemotherapy, $R T$ radiotherapy, $O S$ overall survival, $P F S$ progression-free survival, $D F S$ disease-free survival, FFR failure-free survival, $y$ year, $m$ month, $S Y S U$ Sun Yat-sen University, $H K$ Hong Kong, $P$ cisplatin, $F$ fluorouracil, $q 3 w$ every 3 weeks, $q w$ every week, $d$ day, $q 4 w$ every 4 weeks

${ }^{\mathrm{a}} \mathrm{P} 100$ indicates cisplatin $100 \mathrm{mg} / \mathrm{m}^{2} ; \mathrm{F} 1000 \mathrm{~d} 1-4$ indicates fluorouracil $1000 \mathrm{mg} / \mathrm{m}^{2}$ days $1-4$, etc.

three trials $[67,70,74]$ using CCRT vs. RT alone with different concurrent chemotherapy regimen and all results favored CCRT (Table 5). Similarly, another 3 trials [63, 65, 66, 86, 87] using NeoCT+RT vs. RT alone with different NeoCT regimens and one phase II randomized trial [77] using NeoCT+ CCRT vs. CCRT also demonstrated statistically significant or borderline significant effects favoring the arm containing NeoCT (Table 6). One trial [68] used the design of RT+ AdjCT vs. RT alone by the Taiwan Cooperative Oncology Group (TCOG). The overall survival was not significantly different (most likely due to more unexplained non-cancer deaths in the combined treatment group); however, AdjCT reduced distant metastasis rate from $36.4 \%$ in the RT alone to $19.5 \%$ in the combined treatment arm $(P=0.03)$.

In preparing this mini-review, I did not analyze some trials for a variety of reasons including chemotherapy regimen or dosage [61, 62, 69], small sample size [62, 69], inclusion of early stage tumors [61, 69, 89], and a $2 \times 2$ trial design [71]. Three latest trials, published in 2012 using NeoCT+CCRT vs. CCRT [78], CCRT+AdjCT vs. CCRT
[79], and NeoCT-RT+AdjCT vs. CCRT+AdjCT [80] design, all showed no significant difference in both arms.

Based on above discussion, I believe that adding chemotherapy (no matter what kind - concurrent, neoadjuvant, or adjuvant) to RT will enhance the treatment efficacy beyond RT alone. However, we should not forget that all trials reported substantially increased toxicity associated with combined treatment.

\section{The role of post-radiation adjuvant chemotherapy in NPC}

Who needs adjuvant chemotherapy?

The major goal of AdjCT is to reduce subsequent appearance of distant metastasis. But, not all advanced NPC patients need AdjCT. We should remember that unnecessary or ineffective adjuvant therapy is frequently used. For example, if we treat all patients with a $50 \%$ subsequent distant failure rate and our regimen has a

Table 5 Randomized trials of CCRT vs RT alone

\begin{tabular}{|c|c|c|c|c|c|c|}
\hline Series & Stage & Cases & $\begin{array}{l}\text { Concurrent } \\
\text { chemotherapy }\end{array}$ & $\begin{array}{l}\text { Follow-up } \\
\text { (median) }\end{array}$ & $\begin{array}{l}5 \text {-y OS } \\
\text { CCRT vs RT }\end{array}$ & $\begin{array}{l}\text { 5-y PFS/RFS } \\
\text { CCRT vs RT }\end{array}$ \\
\hline Lin et al. [70] TCVGH, Taiwan & II-IV & 284 & $(\mathrm{P} 20+\mathrm{F} 400) \mathrm{d} 1-4 \mathrm{q} 4 \mathrm{w} \times 2$ & $65 \mathrm{~m}$ & $72.3 \%$ vs $54.2 \%(P=0.0022)$ & $\begin{array}{c}71.6 \% \text { vs } 55.0 \% \\
(P=0.0012)\end{array}$ \\
\hline Chan et al. $[67,88] \mathrm{PWH}, \mathrm{HK}$ & II-IV & 350 & $\mathrm{P} 40 \mathrm{qw} \times 8$ & $66 \mathrm{~m}$ & $70.3 \%$ vs $58.6 \%(P=0.065)$ & $\begin{array}{l}60.2 \% \text { vs } 52.1 \% \\
(P=0.16)\end{array}$ \\
\hline Zhang et al. [74]; SYSU, China & III-IV & 115 & $\mathrm{O} 70 \mathrm{qw} \times 6$ & $24 \mathrm{~m}$ & $100 \%$ vs $77 \%(P=0.01)$ & $\begin{array}{c}96 \% \text { vs } 83 \% \\
(P=0.02)\end{array}$ \\
\hline
\end{tabular}

$C C R T$ concurrent chemoradiotherapy, $R T$ radiotherapy, $O S$ overall survival, $P F S$ progression-free survival, $R F S$ relapse-free survival, $y$ year, $m$ month, TCVGH Taichung Veterans General Hospital, $P W H$ Prince of Wales Hospital, HK Hong Kong, SYSU Sun Yat-sen University, $P$ cisplatin, $F$ fluorouracil, $O$ oxaliplatin, $q 4 w$ every 4 weeks, $q w$ every week, $d$ day 
Table 6 Randomized trials of NeoCT +RT vs RT alone or NeoCT+CCRT vs CCRT

\begin{tabular}{|c|c|c|c|c|c|c|}
\hline Series & Stage & Cases & NeoCT; Concurrent CT & $\begin{array}{l}\text { Follow-up } \\
\text { (median) }\end{array}$ & $\begin{array}{l}\text { OS } \\
\text { NeoCT + RT vs RT }\end{array}$ & $\begin{array}{l}\mathrm{PFS} / \mathrm{DFS} / \mathrm{FFS} \\
\mathrm{CCRT}+\text { AdjCT vs RT }\end{array}$ \\
\hline $\begin{array}{l}\text { Cvitkovic et al. } \\
\text { [64]; INCSG }\end{array}$ & 1987 N2-3 & 339 & $\begin{array}{l}\text { P100d1 E } 70 \text { d1 B15mg } \\
\text { B12d1-5 q3w } \times 3\end{array}$ & $49 \mathrm{~m}$ & $\begin{array}{l}3 \text {-y } 60 \% \text { vs } 54 \% \\
\quad(P>0.05)\end{array}$ & $\begin{array}{l}3 \text {-y } 52 \% \text { vs } 32 \% \\
\quad(P<0.01)\end{array}$ \\
\hline $\begin{array}{l}\text { Chua et al. [65]; } \\
\text { AOCOA }\end{array}$ & $\begin{array}{l}\text { Ho's T3, N2-3 } N \\
>3 \mathrm{~cm}\end{array}$ & 334 & P60 E110 q3w×2-3 & $30 \mathrm{~m}$ & & \\
\hline $\begin{array}{l}\text { Ma et al. [2]; } \\
\text { SYSU, China }\end{array}$ & Chinese III-IV & 556 & $\begin{array}{l}\text { P100d1 B10d-15 F800d1-5 } \\
q 3 w \times 2-3\end{array}$ & $62 \mathrm{~m}$ & & \\
\hline $\begin{array}{l}\text { Pooled above } 2 \\
\text { trials [87] }\end{array}$ & $\begin{array}{l}1997 \text { AJCC } \\
\text { II-IV }\end{array}$ & 784 & & $67 \mathrm{~m}$ & $\begin{array}{l}5 \text {-y } 61.9 \% \text { vs } 53.1 \% \\
\quad(P=0.092)\end{array}$ & $\begin{array}{l}5-\mathrm{y} 50.9 \% \text { vs } 42.7 \% \\
(P=0.014)\end{array}$ \\
\hline $\begin{array}{l}\text { Hui et al. [77]; } \\
\text { PWH HK }\end{array}$ & III-IV & 65 & P75 D75 q3w $\times 2 ;$ P40 qw $\times 8$ & $4.3 \mathrm{y}$ & $\begin{array}{l}3 \text {-y } 94.1 \% \text { vs } 67.7 \% \\
(P=0.012)\end{array}$ & $\begin{array}{l}3 \text {-y } 88.2 \% \text { vs } 59.5 \% \\
(P=0.12)\end{array}$ \\
\hline
\end{tabular}

NeoCT neoadjuvant chemotherapy, $R T$ radiotherapy, $C C R T$ concurrent chemoradiotherapy, $O S$ overall survival, $P F S$ progression-free survival, $D F S$ disease-free survival, FFS failure-free survival, $y$ year, $m$ month, INCSG International Nasopharynx Cancer Study Group, AOCOA Asian-Oceanian Clinical Oncology Association, SYSU Sun Yat-sen University, $P W H$ Prince of Wales Hospital, $H K$ Hong Kong, $P$ cisplatin, $E$ epirubicin, $B$ bleomycin, $F$ fluorouracil, $D$ docetaxel, $q 3 w$ every 3 weeks, $q w$ every week, $d$ day

$50 \%$ control rate for the subclinical disease, the effectiveness of adjuvant therapy is only for $25 \%$ because of unnecessary treatment in $50 \%$ and ineffective treatment of the another $25 \%$. To the best of my knowledge, pEBV DNA and TNM staging currently are two most reliable predictive markers in NPC. With long-term follow-up, two studies from Taiwan showed that the relapse rates for patients with detectable post-treatment pEBV DNA were $71.0 \%(22 / 31)$ among a cohort of 152 patients treated with CCRT [15] and $76.7 \%(23 / 30)$ among a cohort of 210 patients who received NeoCT+ RT [Lin et al. unpublished data]. The sites of failure were predominantly in distant organs in both studies. Among 46 patients with available post-treatment pEBV DNA data, Le et al. from the Stanford University reported a relapse rate of $66.7 \%(8 / 12)$ for patients with persistently detectable pEBV DNA [17]. Compared with post-treatment pEBV DNA levels, the pre-treatment viral load is less effective in predicting subsequent relapses. In Lin's study, 47 of 103 (45.6\%) patients with pretreatment $\mathrm{pEBV}$ DNA $\geq 1,500$ copies $/ \mathrm{mL}$ developed tumor relapse, whereas $21.5 \%(23 / 107)$ patients with pretreatment $\mathrm{pEBV}$ DNA $<1,500$ copies $/ \mathrm{mL}(P=0.0037)$ had tumor relapse [unpublished data]. Regarding the impact of TNM staging on subsequent failure rate, previous reports rarely showed the actual numbers of recurrences among different T-classification, N-classification, and overall stage. Because the reported 5-year diseasefree/relapse-free/metastasis-free survival rates for patients with N3a-b or stage IVA-B are around 40-60\% from large series, I estimate the distant failure and overall relapse rates are about $50 \%$. So, patients with presenting N3a-b or stage IVA-B or who have persistently detectable post-treatment or high pretreatment pEBV DNA appear to require AdjCT.
When to start adjuvant chemotherapy?

Most randomized trials have begun AdjCT 3-4 weeks after completion of RT. However, this time point may not be the best one. NPC patients often are debilitated that soon after a course of curative RT with/without neoadjuvant and/or concurrent chemotherapy. The percentage of patients who could tolerate all planned AdjCT every 4 weeks was between $55 \%$ and $76 \%$, based on the Intergroup study and its reported modifications [64, 72, 73, 75, 76]. Two recent RTOG trials (0225 and 0615 ) reported only $46 \%$ and $48 \%$ of patients completed the 3 cycles of AdjCT [42, 90]. In a phase II study using weekly a schedule of PF plus leucovorin (PFL) and starting about 12 weeks after finishing RT, Lin et al. observed that $87.8 \%(36 / 41)$ of patients could complete 18 weekly cycles of AdjCT [91]. Using a different dose of weekly PFL starting 4 weeks after finishing RT, Chi et al. reported a $52 \%$ compliance rate [68]. Based on the above discussion, it appears that it is the starting date, not the schedule/dosage of AdjCT that determines a patient's compliance. Moreover, there is no evidence to show that moving the start of AdjCT from 3 to 4 weeks to 12 weeks had negative impact on disease control or survival. Although the optimal starting point for AdjCT is unknown at present and should be studied further in the future, the data suggest that starting AdjCT 12 weeks after finishing RT may be preferable to the current general practice of 4 to 6 weeks.

What regimens should be used?

$\mathrm{PF}$ is still the most frequently used regimen for AdjCT of NPC but the conventional schedule (cisplatin around $75-100 \mathrm{mg} / \mathrm{m}^{2}$ on day 1 plus 5 -FU around $4,000 \mathrm{mg} / \mathrm{m}^{2}$ divided in $4-5$ days continuous infusion, repeated every 3-4 weeks) has significant acute toxicity. The reported rates of grade $3 / 4$ mucositis and 
leucopenia are greater than $10 \%$ in randomized trials using this schedule $[64,72,73,75,76]$. Two studies from Taiwan suggested that changing the PF infusion to a weekly 24 -h schedule could greatly reduce toxicity and subsequent distant failure rates $[68,91]$. In the TCOG phase III randomized trial, Chi et al. tested a weekly PFL regimen (cisplatin $20 \mathrm{mg} / \mathrm{m}^{2}+5$-FU $2,200 \mathrm{mg} / \mathrm{m}^{2}+$ leucovorin $120 \mathrm{mg} / \mathrm{m}^{2}$, for 9 weekly cycles) and observed grade 3/4 leucopenia in only 17 of $819(2.1 \%)$ cycles of weekly chemotherapy and no grade $3 / 4$ mucositis [68]. Although this trial was thought to be negative (i.e., no benefit for overall survival), the distant failure rate was reduced from $36.4 \%$ in the control arm to $19.5 \%$ in the treatment arm. Lin et al. used an 18-week PFL regimen (cisplatin $25 \mathrm{mg} / \mathrm{m}^{2}+$ 5 -FU $1,250 \mathrm{mg} / \mathrm{m}^{2}+$ leucovorin $120 \mathrm{mg} / \mathrm{m}^{2}$ ) in 41 high-risk patients and compared the outcome with 88 historic controls without AdjCT [91]. They found that $26.8 \%$ (11/41) of the patients getting PFL and $47.7 \%$ (42/88) patients who did not get AdjCT developed distant metastasis $(P=0.0247)$. The 5year metastasis-free survival rates were $71.9 \%$ for the PFL group compared with $48.4 \%$ for no AdjCT patients $(P=$ $0.0187)$ and the overall survival benefit nearly reached statistically significant ( $53.7 \%$ vs. $38.3 \%, P=0.0666$ ). No mucositis was observed and grade $3 / 4$ leucopenia, anemia, thrombocytopenia, and vomiting were noted in $7.3 \%, 2.4 \%$, $2.4 \%$, and $2.4 \%$ cycles. A recent combined analysis of the pooled data from 441 patients with stage III/IV disease treated in the Hong Kong NPC-9901 and NPC-9902 trials showed that the dose of 5-FU during AdjCT was significantly associated with the distant failure-free rate by multivariate analysis [85]. The 5-year distant failure-free rates for patients who received $0-1,2$, and 3 adjuvant cycles were $68 \%, 78 \%$, and $77 \%$, respectively $(P=0.063)$.

There is no other regimen reported to be as effective in adjuvant setting for NPC as PF. Other regimens that have activity in the neoadjuvant $[63,65,66,77,78,92-94]$ or salvage setting [95-110], of course, can be considered for the adjuvant phase in future trials with some modifications, such as docetaxel [77, 93-96], paclitaxel [78, 102-105], gemcitabine [105-110], mitomycin C [92, 97, 100], epirubicin [63, 92, 99-101], bleomycin [63, 66, 98, 99, 101], and vinorelbine [110]. Recently the RTOG 0615 trial reported that the addition of concurrent and adjuvant targeted therapy (bevacizumab $15 \mathrm{mg} / \mathrm{m}^{2}$ per cycle) to standard chemoradiotherapy for advanced NPC is feasible and might delay the progression of subclinical distant disease [90].

\section{Conclusions}

AdjCT remains a part of the standard of care for advanced stage NPC; however, it may not always be necessary. Future AdjCT trials should be confined to high risk tumors using some combination of $\mathrm{pEBV}$ load and/or high clinical stage to better select appropriate candidates. A phase III randomized trial based on post-radiation residual pEBV DNA load has been ongoing in Hong Kong and similar trials likely will be started by the RTOG and TCOG soon.

Conflict of interest The author has no conflict of interest to disclose.

\section{References}

1. Heng DM, Wee J, Fong KW, Lian LG, Sethi VK, Chua ET, Yang TL, Khoo Tan HS, Lee KS, Lee KM, Tan T, Chua EJ (1999) Prognostic factors in 677 patients in Singapore with nondisseminated nasopharyngeal carcinoma. Cancer 86:1912-1920

2. Ma J, Mai HQ, Hong MH, Cui NJ, Lu TX, Lu LX, Mo HY, Min HQ (2001) Is the 1997 AJCC staging system for nasopharyngeal carcinoma prognostically useful for Chinese patient populations? Int J Radiat Oncol Biol Phys 50:1181-1189

3. Yeh SA, Tang Y, Lui CC, Huang YJ, Huang EY (2005) Treatment outcomes and late complications of 849 patients with nasopharyngeal carcinoma treated with radiotherapy alone. Int J Radiat Oncol Biol Phys 62:672-679

4. Au JS, Law CK, Foo W, Lau WH (2003) In-depth evaluation of the AJCC/UICC 1997 staging system of nasopharyngeal carcinoma: prognostic homogeneity and proposed refinements. Int $\mathbf{J}$ Radiat Oncol Biol Phys 56:413-426

5. Chua DT, Sham JS, Wei WI, Ho WK, Au GK (2001) The predictive value of the 1997 American Joint Committee on Cancer stage classification in determining failure patterns in nasopharyngeal carcinoma. Cancer 92:2845-2855

6. Leung TW, Tung SY, Sze WK, Wong FC, Yuen KK, Lui CM, Lo SH, Ng TY, O SK (2005) Treatment results of 1070 patients with nasopharyngeal carcinoma: an analysis of survival and failure patterns. Head Neck 27:555-565

7. Lee AW, Sze WM, Au JS, Leung SF, Leung TW, Chua DT, Zee BC, Law SC, Teo PM, Tung SY, Kwong DL, Lau WH (2005) Treatment results for nasopharyngeal carcinoma in the modern era: the Hong Kong experience. Int J Radiat Oncol Biol Phys 61:1107-1116

8. Lo YM, Chan LY, Lo KW, Leung SF, Zhang J, Chan AT, Lee JC, Hjelm NM, Johnson PJ, Huang DP (1999) Quantitative analysis of cell-free Epstein-Barr virus DNA in plasma of patients with nasopharyngeal carcinoma. Cancer Res 59:1188-1191

9. Lo YM, Chan LY, Chan AT, Leung SF, Lo KW, Zhang J, Lee JC, Hjelm NM, Johnson PJ, Huang DP (1999) Quantitative and temporal correlation between circulating cell-free Epstein-Barr virus DNA and tumor recurrence in nasopharyngeal carcinoma. Cancer Res 59:5452-5455

10. Lo YM, Chan AT, Chan LY, Leung SF, Lam CW, Huang DP, Johnson PJ (2000) Molecular prognostication of nasopharyngeal carcinoma by quantitative analysis of circulating Epstein-Barr virus DNA. Cancer Res 60:6878-6881

11. Chan AT, Lo YM, Zee B, Chan LY, Ma BB, Leung SF, Mo F, Lai M, Ho S, Huang DP, Johnson PJ (2002) Plasma Epstein-Barr virus DNA and residual disease after radiotherapy for undifferentiated nasopharyngeal carcinoma. J Natl Cancer Inst 94:1614-1619

12. Leung SF, Chan AT, Zee B, Ma BB, Chan LY, Johnson PJ, Lo YM (2003) Pretherapy quantitative measurement of circulating Epstein-Barr virus DNA is predictive of posttherapy distant failure in patients with early-stage nasopharyngeal carcinoma of undifferentiated type. Cancer 98:288-291 
13. Leung SF, Zee B, Ma BB, Hui EP, Mo F, Lai M, Chan KC, Chan LY, Kwan W, Lo YM, Chan AT (2006) Plasma Epstein-Barr viral deoxyribonucleic acid quantitation complements tumor-nodemetastasis staging prognostication in nasopharyngeal carcinoma. J Clin Oncol 24:5414-5418

14. Lin JC, Wang WY, Chen KY, Wei YH, Liang WM, Jan JS, Jiang RS (2004) Quantification of plasma Epstein-Barr virus DNA in patients with advanced nasopharyngeal carcinoma. New Engl J Med 350:2461-2470

15. Lin JC, Wang WY, Liang WM, Chou HY, Jan JS, Jiang RS, Wang JY, Twu CW, Liang KL, Chao J, Shen WC (2007) Long-term prognostic effects of plasma Epstein-Barr Virus DNA by minor groove binder-probe real-time quantitative PCR on nasopharyngeal carcinoma patients receiving concurrent chemoradiotherapy. Int J Radiat Oncol Biol Phys 68:1342-1348

16. Hou X, Chong Z, Guo Y, Han F, Lu LX, Wu SX, Li S, Huang PY, Huang H, Zhang L (2011) Different clinical significance of preand post-treatment plasma Epstein-Barr virus DNA load in nasopharyngeal carcinoma treated with radiotherapy. Clin Oncol 23:128-133

17. Le QT, Jones CD, Yau TK, Shirazi HA, Wong PH, Thomas EN, Patterson BK, Lee AW, Zehnder JL (2005) A comparison study of different PCR assays in measuring circulating plasma EpsteinBarr virus DNA levels in patients with nasopharyngeal carcinoma. Clin Cancer Res 11:5700-5707

18. Huang S, Chu G (1981) Nasopharyngeal cancer: study II. Int J Radiat Oncol Biol Phys 7(6):713-716

19. Huang SC, Lui LT, Lynn TC (1985) Nasopharyngeal cancer: study III. A review of 1206 patients treated with combined modalities. Int J Radiat Oncol Biol Phys 10:1789-1793

20. Qin DX, Hu YH, Yan JH, Xu GZ, Cai WM, Wu XL, Cao DX, Gu XZ (1988) Analysis of 1379 patients with nasopharyngeal carcinoma treated by radiation. Cancer 61(6):1117-1124

21. Chen WZ, Zhou DL, Luo KS (1989) Long-term observation after radiotherapy for nasopharyngeal carcinoma (NPC). Int J Radiat Oncol Biol Phys 16(2):311-314

22. Zhang EP, Lian PG, Cai KL, Chen YF, Cai MD, Zheng XF, Guang XX (1989) Radiation therapy of nasopharyngeal carcinoma: prognostic factors based on a 10-year follow-up of 1302 patients. Int J Radiat Oncol Biol Phys 16(2):301-305

23. Lee AW, Poon YF, Foo W, Law SC, Cheung FK, Chan DK, Tung SY, Thaw M, Ho JH (1992) Retrospective analysis of 5037 patients with nasopharyngeal carcinoma treated during 19761985: overall survival and patterns of failure. Int J Radiat Oncol Biol Phys 23(2):261-270

24. Sham JS, Choy D (1990) Prognostic factors of nasopharyngeal carcinoma: a review of 759 patients. Br J Radiol 63 (745):51-58

25. Sanguineti G, Geara FB, Garden AS, Tucker SL, Ang KK, Morrison WH, Peters LJ (1997) Carcinoma of the nasopharynx treated by radiotherapy alone: determinants of local and regional control. Int J Radiat Oncol Biol Phys 37(5):985-996

26. Geara FB, Sanguineti G, Tucker SL, Garden AS, Ang KK, Morrison WH, Peters LJ (1997) Carcinoma of the nasopharynx treated by radiotherapy alone: determinants of distant metastasis and survival. Radiother Oncol 43(1):53-61

27. Vikram B, Mishra UB, Strong EW, Manolatos S (1985) Patterns of failure in carcinoma of the nasopharynx: I. Failure at the primary site. Int J Radiat Oncol Biol Phys 11(8):1455-1459

28. Vikram B, Mishra UB, Strong EW, Manolatos S (1986) Patterns of failure in carcinoma of the nasopharynx: failure at distant sites. Head Neck Surg 8(4):276-279

29. Perez CA, Devineni VR, Marcial-Vega V, Marks JE, Simpson JR, Kucik N (1992) Carcinoma of the nasopharynx: factors affecting prognosis. Int J Radiat Oncol Biol Phys 23(2):271280
30. Bailet JW, Mark RJ, Abemayor E, Lee SP, Tran LM, Juillard G, Ward PH (1992) Nasopharyngeal carcinoma: treatment results with primary radiation therapy. Laryngoscope 102(9):965-972

31. Lai SZ, Li WF, Chen L, Luo W, Chen YY, Liu LZ, Sun Y, Lin AH, Liu MZ, Ma J (2011) How does intensity-modulated radiotherapy versus conventional two-dimensional radiotherapy influence the treatment results in nasopharyngeal carcinoma patients? Int J Radiat Oncol Biol Phys 80(3):661-668

32. Hong MH, Mai HQ, Min HQ, Ma J, Zhang EP, Cui NJ (2000) A comparison of the Chinese 1992 and fifth-edition International Union Against Cancer staging systems for staging nasopharyngeal carcinoma. Cancer 89:242-247

33. Lu JC, Wei BQ, Chen WZ, Qian PD, Zhang YQ, Wei Q, Cha WW, Li F, Ni M (2006) Staging of nasopharyngeal carcinoma investigated by magnetic resonance imaging. Radiother Oncol 79:21-26

34. Liu MZ, Tang LL, Zong JF, Huang Y, Sun Y, Mao YP, Liu LZ, Lin AH, Ma J (2008) Evaluation of sixth edition of AJCC staging system for nasopharyngeal carcinoma and proposed improvement. Int J Radiat Oncol Biol Phys 70:1115-1123

35. Cheng SH, Tsai SY, Horng CF, Yen KL, Jian JJ, Chan KY, Lin CY, Terng SD, Tsou MH, Chu NM, Chen HH, Chen PL, Chung YL, Hsieh CI, Tan TD, Huang AT (2006) A prognostic scoring system for locoregional control in nasopharyngeal carcinoma following conformal radiotherapy. Int J Radiat Oncol Biol Phys 66:992-1003

36. Yi JL, Gao L, Huang XD, Li SY, Luo JW, Cai WM, Xiao JP, Xu GZ (2006) Nasopharyngeal carcinoma treated by radical radiotherapy alone: ten-year experience of a single institution. Int $\mathrm{J}$ Radiat Oncol Biol Phys 65:161-168

37. Kwong DL, Sham JS, Leung LH, Cheng AC, Kwong PW, Lui WM, Yau CC, Wu PM, Wei W, Au G (2006) Preliminary results of radiation dose escalation for locally advanced nasopharyngeal carcinoma. Int J Radiat Oncol Biol Phys 64:374-381

38. Wolden SL, Chen WC, Pfister DG, Kraus DH, Berry SL, Zelefsky MJ (2006) Intensity-modulated radiation therapy (IMRT) for nasopharynx cancer: update of the Memorial Sloan-Kettering experience. Int J Radiat Oncol Biol Phys 64:57-62

39. Kam MK, Teo PM, Chau RM, Cheung KY, Choi PH, Kwan WH, Leung SF, Zee B, Chan AT (2004) Treatment of nasopharyngeal carcinoma with intensity-modulated radiotherapy: the Hong Kong experience. Int J Radiat Oncol Biol Phys 60:1440-1450

40. Lee N, Xia P, Quivey JM, Sultanem K, Poon I, Akazawa C, Akazawa P, Weinberg V, Fu KK (2002) Intensity-modulated radiotherapy in the treatment of nasopharyngeal carcinoma: an update of the UCSF experience. Int J Radiat Oncol Biol Phys $53: 12-22$

41. Xiao WW, Huang SM, Han F, Wu SX, Lu LX, Lin CG, Deng XW, Lu TX, Cui NJ, Zhao C (2011) Local control, survival, and late toxicities of locally advanced nasopharyngeal carcinoma treated by simultaneous modulated accelerated radiotherapy combined with cisplatin concurrent chemotherapy: long-term results of a phase 2 study. Cancer 117(9):1874-1883

42. Lee N, Harris J, Garden AS, Straube W, Glisson B, Xia P, Bosch W, Morrison WH, Quivey J, Thorstad W, Jones C, Ang KK (2009) Intensity-modulated radiation therapy with or without chemotherapy for nasopharyngeal carcinoma: radiation therapy oncology group phase II trial 0225. J Clin Oncol 27(22):36843690

43. Lin S, Pan J, Han L, Zhang X, Liao X, Lu JJ (2009) Nasopharyngeal carcinoma treated with reduced-volume intensity-modulated radiation therapy: report on the 3-year outcome of a prospective series. Int J Radiat Oncol Biol Phys 75(4):1071-1078

44. Tham IW, Hee SW, Yeo RM, Salleh PB, Lee J, Tan TW, Fong KW, Chua ET, Wee JT (2009) Treatment of nasopharyngeal carcinoma using intensity-modulated radiotherapy - the National 
Cancer Center Singapore experience. Int J Radiat Oncol Biol Phys 75(5):1481-1486

45. Wong FC, Ng AW, Lee VH, Lui CM, Yuen KK, Sze WK, Leung TW, Tung SY (2010) Whole-field simultaneous integrated-boost intensity-modulated radiotherapy for patients with nasopharyngeal carcinoma. Int J Radiat Oncol Biol Phys 76(1):138-145

46. Ng WT, Lee MC, Hung WM, Choi CW, Lee KC, Chan OS, Lee AW (2011) Clinical outcomes and patterns of failure after intensity-modulated radiotherapy for nasopharyngeal carcinoma. Int J Radiat Oncol Biol Phys 79(2):420-428

47. Bakst RL, Lee N, Pfister DG, Zelefsky MJ, Hunt MA, Kraus DH, Wolden SL (2011) Hypofractionated dose-painting intensity modulated radiation therapy with chemotherapy for nasopharyngeal carcinoma: a prospective trial. Int J Radiat Oncol Biol Phys 80(1):148-153

48. Chang YS, Tyan YS, Liu ST, Tsai MS, Pao CC (1990) Detection of Epstein-Barr virus DNA sequences in nasopharyngeal carcinoma cells by enzymatic DNA amplification. J Clin Microbiol 28:2398-2402

49. Chen CL, Wen WN, Chen JY, Hsu MM, Hsu HC (1993) Detection of Epstein-Barr virus genome in nasopharyngeal carcinoma by in situ DNA hybridization. Intervirology 36:91-98

50. Tsai ST, Jin YT, Su IJ (1996) Expression of EBER1 in primary and metastatic nasopharyngeal carcinoma tissues using in situ hybridization. A correlation with WHO histologic subtypes. Cancer 77:231-236

51. Raab-Traub N, Flynn K (1986) The structure of the termini of the Epstein-Barr virus as a marker of clonal cellular proliferation. Cell 47:883-889

52. Henle W, Henle G, Ho HC, Burtin P, Cachin Y, Clifford P, de Schryver A, de-Thé G, Diehl V, Klein G (1970) Antibodies to Epstein-Barr virus in nasopharyngeal carcinoma, other head and neck neoplasms and control groups. J Natl Cancer Inst 44:225231

53. Henle G, Henle W (1976) Epstein-Barr virus-specific IgA serum antibodies as an outstanding feature of nasopharyngeal carcinoma. Int J Cancer 17:1-7

54. Ho HC, Ng MH, Kwan HC, Chau JC (1976) Epstein-Barr virusspecific $\operatorname{IgA}$ and $\operatorname{IgG}$ serum antibodies in nasopharyngeal carcinoma. Br J Cancer 34:655-660

55. Chien YC, Chen JY, Liu MY, Yang HI, Hsu MM, Chen CJ, Yang CS (2001) Serologic markers of Epstein-Barr virus infection and nasopharyngeal carcinoma in Taiwanese men. $\mathrm{N}$ Engl J Med 345:1877-1882

56. Zeng Y, Zhong JM, Li LY, Wang PZ, Tang H, Ma YR, Zhu JS, Pan WJ, Liu YX, Wei ZN et al (1983) Follow-up studies on Epstein-Barr virus IgA/VCA antibody-positive persons in Zangwu County, China. Intervirology 20:190-194

57. Ma BB, King A, Lo YM, Yau YY, Zee B, Hui EP, Leung SF, Mo F, Kam MK, Ahuja A, Kwan WH, Chan AT (2006) Relationship between pretreatment level of plasma Epstein-Barr virus DNA, tumor burden, and metabolic activity in advanced nasopharyngeal carcinoma. Int J Radiat Oncol Biol Phys 66:714-720

58. Kondo S, Horikawa T, Takeshita H, Kanegane C, Kasahara Y, Sheen TS, Sato H, Furukawa M, Yoshizaki T (2004) Diagnostic value of serum EBV-DNA quantification and antibody to viral capsid antigen in nasopharyngeal carcinoma patients. Cancer Sci 95:508-513

59. Tan EL, Selvaratnam G, Kananathan R, Sam CK (2006) Quantification of Epstein-Barr virus DNA load, interleukin-6, interleukin-10, transforming growth factor- $\beta 1$ and stem cell factor in plasma of patients with ansopharyngeal carcinoma. BMC Cancer 6:227

60. Bortolin MT, Pratesi C, Dolcetti R, Bidoli E, Vaccher E, Zanussi S, Tedeschi R, Paoli PD (2006) Clinical value of Epstein-Barr virus DNA levels in peripheral blood samples of Italian patients with undifferentiated carcinoma of nasopharygneal type. Cancer Let 233:247-254

61. Rossi A, Molinari R, Boracchi P, Del Vecchio M, Marubini E, Nava M, Morandi L, Zucali R, Pilotti S, Grandi C, Ambrosini G, Cellini N, Chiavacci A, Colombo A, Fior SD, Maria DD, Felci U, Gabriele P, Laddaga M, Magno L, Marziano C, Olmi P, Prino A, Roncoroni L, Torretta A, Zampi G, Zorat PL, Palo GD (1988) Adjuvant chemotherapy with vincristine, cyclophosphamide, and doxorubicin after radiotherapy in local-regional nasopharyngeal cancer: results of a 4-year multicenter randomized study. J Clin Oncol 6:1401-1410

62. Chan AT, Teo PM, Leung TW, Leung SF, Lee WY, Yeo W, Choi PH, Johnson PJ (1995) A prospective randomized study of chemotherapy adjunctive to definitive radiotherapy in advanced nasopharyngeal carcinoma. Int J Radiat Oncol Biol Phys 33:569-577

63. Cvitkovic E, and the International Nasopharynx Cancer Study Group (1996) Preliminary results of a randomized trial comparing neoadjuvant chemotherapy (cisplatin, epirubicin, bleomycin) plus radiotherapy vs. radiotherapy alone in stage IV $(\geqq N 2, M 0)$ undifferentiated nasopharyngeal carcinoma: a positive effect on progression-free survival. Int J Radiat Oncol Biol Phys 35:463-469

64. Al-Sarraf M, LeBlanc M, Giri PG, Fu KK, Cooper J, Vuong T, Forastiere AA, Adams G, Sakr WA, Schuller DE, Ensley JF (1998) Chemoradiotherapy versus radiotherapy in patients with advanced nasopharyngeal cancer: phase III randomized Intergroup study 0099. J Clin Oncol 16:1310-1317

65. Chua DT, Sham JS, Choy D, Lorvidhaya V, Sumitsawan Y, Thongprasert S, Vootiprux Cheirsilpa A, Azhar T, Reksodiputro AH (1998) Preliminary report of the Asian-Oceanian Clinical Oncology Association randomized trial comparing cisplatin and epirubicin followed by radiotherapy versus radiotherapy alone in the treatment of patients with locoregionally advanced nasopharyngeal carcinoma. Cancer 83:2270-2283

66. Ma J, Mai HQ, Hong MH, Min HQ, Mao ZD, Cui NJ, Lu TX, Mo HY (2001) Results of a prospective randomized trial comparing neoadjuvant chemotherapy plus radiotherapy with radiotherapy alone in patients with locoregionally advanced nasopharyngeal carcinoma. J Clin Oncol 19:1350-1357

67. Chan AT, Teo PM, Ngan RK, Leung TW, Lau WH, Zee B, Leung SF, Cheung FY, Yeo W, Yiu HH, Yu KH, Chiu KW, Chan DT, Mok T, Yuen KT, Mo F, Lai M, Kwan WH, Choi P, John PJ (2002) Concurrent chemotherapy-radiotherapy compared with radiotherapy alone in locoregionally advanced nasopharyngeal carcinoma: progression-free survival analysis of a phase III randomized trial. J Clin Oncol 20:2038-2044

68. Chi KH, Chang YC, Guo WY, Leung MJ, Shiau CY, Chen SY, Wang LW, Lai YL, Hsu MM, Lian SL, Chang CH, Liu TW, Chin YH, Yen SH, Perng CH, Chen KY (2002) A phase III study of adjuvant chemotherapy in advanced nasopharyngeal carcinoma patients. Int J Radiat Oncol Biol Phys 52:1238-1244

69. Hareyama M, Sakata K, Shirato H, Nishioka T, Nishio M, Suzuki K, Saitoh A, Oouchi A, Fukuda S, Himi T (2002) A prospective, randomized trial comparing neoadjuvant chemotherapy with radiotherapy alone in patients with advanced nasopharyngeal carcinoma. Cancer 94:2217-2223

70. Lin JC, Jan JS, Hsu CY, Liang WM, Jiang RS, Wang WY (2003) Phase III study of concurrent chemoradiotherapy versus radiotherapy alone for advanced nasopharyngeal carcinoma: positive effect on overall and progression-free survival. J Clin Oncol 21:631-637

71. Kwong DL, Sham JS, Au GK, Chua DT, Kwong PW, Cheng AC, Wu PM, Law MW, Kwok CC, Yau CC, Wan KY, Chan RT, Choy DD (2004) Concurrent and adjuvant chemotherapy for nasopharyngeal carcinoma: a factorial study. J Clin Oncol 22:2643-2653

72. Lee AW, Lau WH, Tung SY, Chua DT, Chappell R, Xu L, Siu L, Sze WM, Leung TW, Sham JS, Ngan RK, Law SC, Yau TK, Au 
JS, O’Sullivan B, Pang ES, O SK, Au GK, Lau JT, Hong Kong Nasopharyngeal Cancer Study Group (2005) Preliminary results of a randomized study on therapeutic gain by concurrent chemotherapy for regionally-advanced nasopharyngeal carcinoma: NPC-9901 Trial by the Hong Kong Nasopharyngeal Cancer Study Group. J Clin Oncol 23:6966-6975

73. Wee J, Tan EH, Tai BC, Wong HB, Leong SS, Tan T, Chua ET, Yang E, Lee KM, Fong KW, Tan HS, Lee KS, Loong S, Sethi V, Chua EJ, Machin D (2005) Randomized trial of radiotherapy versus concurrent chemoradiotherapy followed by adjuvant chemotherapy in patients with American Joint Committee on Cancer/ International Union Against Cancer stage III and IV nasopharyngeal cancer of the endemic variety. J Clin Oncol 23:6730-6738

74. Zhang L, Zhao C, Peng PJ, Lu LX, Huang PY, Han F, Wu SX (2005) Phase III study comparing standard radiotherapy with or without weekly oxaliplatin in treatment of locoregionally advanced nasopharyngeal carcinoma: preliminary results. J Clin Oncol 23:8461-8468

75. Lee AW, Tung SY, Chan AT, Chappell R, Fu YT, Lu TX, Tan T, Chua DT, O'sullivan B, Xu SL, Pang ES, Sze WM, Leung TW, Kwan WH, Chan PT, Liu XF, Tan EH, Sham JS, Siu L, Lau WH (2006) Preliminary results of a randomized study (NPC-9902 trial) on therapeutic gain by concurrent chemotherapy and/or accelerated fractionation for locally advanced nasopharyngeal carcinoma. Int J Radiat Oncol Biol Phys 66:142-151

76. Chen Y, Liu MZ, Liang SB, Zong JF, Mao YP, Tang LL, Guo Y, Lin AH, Zeng XF, Ma J (2008) Preliminary results of a prospective randomized trial comparing concurrent chemoradiotherapy plus adjuvant chemotherapy with radiotherapy alone in patients with locoregionally advanced nasopharyngeal carcinoma in endemic regions of China. Int J Radiat Oncol Biol Phys 71:13561364

77. Hui EP, Ma BB, Leung SF, King AD, Mo F, Kam MK, Yu BK, Chiu SK, Kwan WH, Ho R, Chan I, Ahuja AT, Zee BC, Chan AT (2009) Randomized phase II trial of concurrent cisplatinradiotherapy with or without neoadjuvant decetaxel and cisplatin in advanced nasopharyngeal carcinoma. J Clin Oncol 27:242-249

78. Fountzilas G, Ciuleanu E, Bobos M, Kalogera-Fountzila A, Eleftheraki AG, Karayannopoulou G, Zaramboukas T, Nikolaou A, Markou K, Resiga L, Dionysopoulos D, Samantas E, Athanassiou H, Misailidou D, Skarlos D, Ciuleanu T (2012) Induction chemotherapy followed by concomitant radiotherapy and weekly cisplatin versus the same concomitant chemoradiotherapy in patients with nasopharyngeal carcinoma: a randomized phase II study conducted by the Hellenic Cooperative Oncology Group (HeCOG) with biomarker evaluation. Ann Oncol 23 (2):427-435

79. Chen L, Hu CS, Chen XZ, Hu GQ, Cheng ZB, Sun Y, Li WX, Chen YY, Xie FY, Liang SB, Chen Y, Xu TT, Li B, Long GX, Wang SY, Zheng BM, Guo Y, Sun Y, Mao YP, Tang LL, Chen YM, Liu MZ, Ma J (2012) Concurrent chemoradiotherapy plus adjuvant chemotherapy versus concurrent chemoradiotherapy alone in patients with locoregionally advanced nasopharyngeal carcinoma: a phase 3 multicentre randomized controlled trial. Lancet Oncol 13(2):163-171

80. Xu T, Hu C, Zhu G, He X, Wu Y, Ying H (2012) Preliminary results of a phase III randomized study comparing chemotherapy neoadjuvantly or concurrently with radiotherapy for locoregionally advanced nasopharyngeal carcinoma. Med Oncol 29(1):272-278

81. Al-Sarraf M, LeBlanc M, Giri PG, Fu KK, Cooper J, Vuong T, Forastiere AA, Adams G, Sakr WA, Schuller DE, Ensley JF (1998) Chemo-radiotherapy vs radiotherapy in patients with advanced nasopharyngeal cancer. Intergroup (0099) phase III study: progress report. J Clin Oncol 17:385a, abstract 1483

82. Wee J, Tan EH, Tai BC, Wong HB, Leong SS, Tan T, Chua ET, Lee KM, Fong KW, Machin D (2006) Final report of SQNP01 — a phase
III randomized trial comparing RT with chemo-RT for locally advanced nasopharyngeal cancer. ASTRO 2006 abstract 28 .

83. Lee AW, Tung SY, Chua DT, Ngan RKC, Chappell R, Tung R, Siu L, Ng WT, Sze WK, Au GK, Law SCK, O’Sullivan B, Yau TK, Leung TW, Au JSK, Sze WM, Choi CW, Fung KK, Lau JT, Lau WH (2010) Randomized trial of radiotherapy plus concurrent-adjuvant chemotherapy vs radiotherapy alone for regionally advanced. J Natl Cancer Inst 102:1188-1198

84. Lee AW, Tung SY, Chan AT, Chappell R, Fu YT, Lu TX, Tan T, Chua DT, O'Sullivan B, Tung R, Ng WT, Leung TW, Leung SF, Yau S, Zhao C, Tan EH, Au GK, Siu L, Fung KK, Lau WH (2011) A randomized trial on addition of concurrent-adjuvant chemotherapy and/or accelerated fractionation for locallyadvanced nasopharyngeal carcinoma. Radiother Oncol 98 (1): $15-22$

85. Lee AW, Tung SY, Ngan RK, Chappell R, Chua DT, Lu TX, Siu L, Tan T, Chan LK, Ng WT, Leung TW, Fu YT, Au GK, Zhao C, O'Sullivan B, Tan EH, Lau WH (2011) Factors contributing to the efficacy of concurrent-adjuvant chemotherapy for locoregionally advanced nasopharyngeal carcinoma: combined analyses of NPC9901 and NPC-9902 Trials. Eur J Cancer 47(5):656-666

86. Chua DT, Ma J, Sham JS, Mai HQ, Choy DT, Hong MH, Lu TX, Au GK, Min HQ (2006) Improvement of survival after addition of induction chemotherapy to radiotherapy in patients with earlystage nasopharyngeal carcinoma: Subgroup analysis of two Phase III trials. Int J Radiat Oncol Biol Phys 65(5):1300-1306

87. Chua DT, Ma J, Sham JS, Mai HQ, Choy DT, Hong MH, Lu TX, Min HQ (2005) Long-term survival after cisplatin-based induction chemotherapy and radiotherapy for nasopharyngeal carcinoma: a pooled data analysis of two phase III trials. J Clin Oncol 23:1118-1124

88. Chan AT, Leung SF, Ngan RK, Teo PM, Lau WH, Kwan WH, Hui EP, Yiu HY, Yeo W, Cheung FY, Yu KH, Chiu KW, Chan DT, Mok TS, Yau S, Yuen KT, Mo FK, Lai MM, Ma BB, Kam MK, Leung TW, Johnson PJ, Choi PH, Zee BC (2005) Overall survival after concurrent cisplatin-radiotherapy compared with radiotherapy alone in locoregionally advanced nasopharyngeal carcinoma. J Natl Cancer Inst 97:536-539

89. Chen QY, Wen YF, Guo L, Liu H, Huang PY, Mo HY, Li NW, Xiang YQ, Luo DH, Qiu F, Sun R, Deng MQ, Chen MY, Hua YJ, Guo X, Cao KJ, Hong MH, Qian CN, Mai HQ (2011) Concurrent chemoradiotherapy vs radiotherapy alone in stage II nasopharyngeal carcinoma: phase III randomized trial. J Natl Cancer Inst 103:1-10

90. Lee NY, Zhang Q, Pfister DG, Kim J, Garden AS, Mechalakos J, $\mathrm{Hu}$ K, Le QT, Colevas AD, Glisson BS, Chan ATC, Ang KK (2012) Addition of bevacizumab to standard chemoradiation for locoregionally advanced nasopharyngeal carcinoma (RTOG 0615): a phase 2 multi-institutional trial. Lancet Oncol 13:172180

91. Lin JC, Jan JS, Chen KY, Hsu CY, Liang WM, Wang WY (2003) Outpatient weekly 24-hour infusional adjuvant chemotherapy of cisplatin, 5-fluorouracil, and leucovorin for high-risk nasopharyngeal carcinoma. Head Neck 25:438-450

92. Hong RL, Ting LL, Ko JY, Hsu MM, Sheen TS, Lou PJ, Wang CC, Chung NN, Lui LT (2001) Induction chemotherapy with mitomycin, epirubicin, cisplatin, fluorouracil, and leucovorin followed by radiotherapy in the treatment of locoregionally advanced nasopharyngeal carcinoma. J Clin Oncol 19:4305-4313

93. Bossi P, Orlandi E, Bergamini C, Locati LD, Granata R, Mirabile A, Parolini D, Franceschini M, Fallai C, Olmi P, Quattrone P, Potepan P, Gloghini A, Miceli R, Mattana F, Scaramellini G, Licitra L (2012) Docetaxel, cisplatin and 5-fluorouracil-based induction chemotherapy followed by intensity-modulated radiotherapy concurrent with cisplatin in locally advanced EBV-related nasopharyngeal cancer. Ann Oncol 22(11):2495-2500 
94. Ekenel M, Keskin S, Basaran M, Ozdemir C, Meral R, Altun M, Aslan I, Bavbek SE (2011) Induction chemotherapy with docetaxel and cisplatin is highly effective for locally advanced nasopharyngeal carcinoma. Oral Oncol 47(7):660-664

95. Chua DT, Sham JS, Au GK (2005) A phase II study of docetaxel and cisplatin as first-line chemotherapy in patients with metastatic nasopharyngeal carcinoma. Oral Oncol 41:589-595

96. Ngeow J, Lim WT, Leong SS, Ang MK, Toh CK, Gao F, Chowbay B, Tan EH (2011) Docetaxel is effective in heavily pretreated patients with disseminated nasopharyngeal carcinoma. Ann Oncol 22:718-722

97. Hong RL, Sheen TS, Ko JY, Hsu MM, Wang CC, Ting LL (1999) Induction with mitomycin $\mathrm{C}$, doxorubicin, cisplatin and maintenance with weekly 5-fluorouracil, leucovorin for treatment of metastatic nasopharyngeal carcinoma: a phase II study. Br J Cancer 80:1962-1967

98. Boussen H, Cvitkovic E, Wendling JL, Azli N, Bachouchi M, Mahjoubi R, Kalifa C, Wibault P, Schwaab G, Armand JP (1991) Chemotherapy of metastatic and/or recurrent undifferentiated nasopharyngeal carcinoma with cisplatin, bleomycin, and fluorouracil. J Clin Oncol 9:1675-1681

99. Azli N, Fandi A, Bachouchi M, Rahal M, Lianes P, Wibault P, Boussen H, Eschwege F, Armand JP, Cvitkovic E (1995) Final report of a phase II study of chemotherapy with bleomycin, epirubicin, and cisplatin for locally advanced and metastatic/ recurrent undifferentiated carcinoma of the nasopharyngeal type. Cancer J Sci Am 1:222-229

100. Hasbini A, Mahjoubi R, Fandi A, Chouaki N, Taamma A, Lianes $\mathrm{P}$, Cortès-Funes $\mathrm{H}$, Alonso $\mathrm{S}$, Armand JP, Cvitkovic E, Raymond E (1999) Phase II trial combining mitomycin with 5-fluorouracil, epirubicin, and cisplatin in recurrent and metastatic undifferentiated carcinoma of nasopharyngeal type. Ann Oncol 10:421-425

101. Taamma A, Fandi A, Azli N, Wibault P, Chouaki N, Hasbini A, Couteau C, Armand JP, Cvitkovic E (1999) Phase II trial of chemotherapy with 5-fluorouracil, bleomycin, epirubicin, and cisplatin for patients with locally advanced, metastatic, or recurrent undifferentiated carcinoma of the nasopharyngeal type. Cancer $86: 1101-1108$
102. Au E, Tan EH, Ang PT (1998) Activity of paclitaxel by threehour infusion in Asian patients with metastatic undifferentiated nasopharyngeal cancer. Ann Oncol 9:327-329

103. Yeo W, Leung TW, Chan AT, Chiu SK, Yu P, Mok TS, Johnson PJ (1998) A phase II study of combination paclitaxel and carboplatin in advanced nasopharyngeal carcinoma. Eur J Cancer 34:2027-2031

104. Tan EH, Khoo KS, Wee J, Fong KW, Lee KS, Lee KM, Chua ET, Tan T, Hs K-T, Yang TL, Au E, Tao M, Ong YK, Chua EJ (1999) Phase II trial of a paclitaxel and carboplatin combination in Asian patients with metastatic nasopharyngeal carcinoma. Ann Oncol 10:235-237

105. Ma BB, Tannock IF, Pond GR, Edmonds MR, Siu LL (2002) Chemotherapy with gemcitabine-containing regimens for locally recurrent or metastatic nasopharyngeal carcinoma. Cancer 95:2516-2523

106. Ngan RK, Yiu HH, Lau WH, Yau S, Cheung FY, Chan TM, Kwok CH, Chiu CY, Au SK, Foo W, Law CK, Tse KC (2002) Combination gemcitabine and cisplatin chemotherapy for metastatic or recurrent nasopharyngeal carcinoma: report of a phase II study. Ann Oncol 13:1252-1258

107. Leong SS, Wee J, Rajan S, Toh CK, Lim WT, Hee SW, Tay MH, Poon D, Tan EH (2008) Triplet combination of gemcitabine, paclitaxel, and carboplatin followed by maintenance 5-fluorouracil and folinic acid in patients with metastatic nasopharyngeal carcinoma. Cancer 113:1332-1337

108. Ma BB, Hui EP, Wong SC, Tung SY, Yuen KK, King A, Chan SL, Leung SF, Kam MK, Yu BK, Zee B, Chan AT (2009) Multicenter phase II study of gemcitabine and oxaliplatin in advanced nasopharyngeal carcinoma - correlation with excision repair crosscomplementing-1 polymorphisms. Ann Oncol 20:1854-1859

109. Zhang L, Zhang Y, Huang PY, Xu F, Peng PJ, Guan ZZ (2008) Phase II clinical study of gemcitabine in the treatment of patients with advanced nasopharyngeal carcinoma after the failure of platinum-based chemotherapy. Canc Chemother Pharmacol 61:33-38

110. Wang CC, Chang JY, Liu TW, Lin CY, Yu YC, Hong RL (2006) Phase II study of gemcitabine plus vinorelbine in the treatment of cisplatin-resistant nasopharyngeal carcinoma. Head Neck 28:74-80 